\title{
FOXP3 expression is modulated by TGF-ß31/NOTCH1 pathway in human melanoma
}

\author{
EVA SKARMOUTSOU ${ }^{1}$, VALENTINA BEVELACQUA ${ }^{1}$, FABIO D' AMICO $^{1}$, ANGELA RUSSO ${ }^{1}$, \\ DEMETRIOS A. SPANDIDOS ${ }^{2}$, AURORA SCALISI $^{3}$, GRAZIA MALAPONTE ${ }^{* *}$ and CLAUDIO GUARNERI ${ }^{*}$ \\ ${ }^{1}$ Department of Biomedical and Biotechnological Science, University of Catania, 95124 Catania, Italy; ${ }^{2}$ Laboratory of \\ Clinical Virology, Medical School, University of Crete, 71003 Heraklion, Crete, Greece; ${ }^{3}$ Unit of Oncologic Diseases, \\ ASP-Catania, 95100 Catania; ${ }^{4}$ Research Unit of the Catania Section of the Italian League Against Cancer, 95122 Catania; \\ ${ }^{5}$ Department of Clinical and Experimental Medicine, Section of Dermatology, \\ University of Messina, 98122 Messina, Italy
}

Received March 1, 2018; Accepted April 4, 2018

DOI: 10.3892/ijmm.2018.3618

\begin{abstract}
Forkhead box protein 3 (FOXP3) transcription factor is expressed by immune cells and several human cancers and is associated with tumor aggressiveness and unfavorable clinical outcomes. NOTCH and transforming growth factor- $\beta$ (TGF- $\beta$ ) protumorigenic effects are mediated by FOXP3 expression in several cancer models; however, their interaction and role in melanoma is unknown. We investigated TGF- $\beta$-induced FOXP3 gene expression during NOTCH1 signaling inactivation. Primary (WM35) and metastatic melanoma (A375 and A2058) cell lines and normal melanocytes (NHEM) were used. FOXP3 subcellular distribution was evaluated by immunocytochemical analysis. Gene expression levels were assessed by reverse transcription-quantitative polymerase chain reaction. Protein levels were assessed by western blot analysis. The $\gamma$-secretase inhibitor (GSI) was used for NOTCH1 inhibition and recombinant human (rh)TGF- $\beta$ was used for melanoma cell stimulation. Cell proliferation and viability were respectively assessed by MTT and Trypan blue dye assays. FOXP3 mRNA and protein levels were progressively higher in WM35, A375 and A2058 cell lines compared to NHEM and their levels were further increased after stimulation with rh-TGF- $\beta$. TGF- $\beta$-mediated FOXP3 expression was mediated by NOTCH1 signaling. Inhibition of NOTCH1 with concomitant rh-TGF- $\beta$ stimulation determined the reduction in gene expression and protein level of FOXP3. Finally, melanoma cell line proliferation and viability were reduced by NOTCH1 inhibition. The results show that $n n$ increase in FOXP3 expres-
\end{abstract}

Correspondence to: Dr Claudio Guarneri, Department of Clinical and Experimental Medicine, Section of Dermatology, University of Messina, Piazza Pugliatti 1, 98122 Messina, Italy

E-mail: cguarneri@unime.it

${ }^{*}$ Contributed equally

Key words: melanoma, FOXP3, NOTCH pathway, TGF- $\beta$, targeted therapy sion in metastatic melanoma cell lines is a potential marker of tumor aggressiveness and metastasis. NOTCH1 is a central mediator of TGF- $\beta$-mediated FOXP3 expression and NOTCH1 inhibition produces a significant reduction of melanoma cell proliferation and viability.

\section{Introduction}

Among all skin tumors, melanoma is the most aggressive form because of rapid metastasis and resistance to conventional radio- and chemotherapy (1-3). The advances in understanding the microenvironment of melanoma and cell biology make it obvious that the treatment needs to be multi-directional. Melanoma is a highly immunogenic tumor (4) and numerous immunotherapeutic strategies have been tested (5-8). Although it has been demonstrated that the various immune-based therapies induce an increase in circulating tumor antigen-specific $\mathrm{T}$ cells, these approaches have produced a poor therapy response, due to tumor-induced immune suppression and tumor evasion of anti-tumor immune responses (9).

Regulatory $\mathrm{T}$ cells (Tregs) are $\mathrm{CD} 4^{+} \mathrm{CD} 25^{+}$cells characterized by the forkhead box protein 3 (FOXP3) transcription factor expression, which is the most specific marker for Tregs $(10,11)$. These cells exert an immunosuppressive function and FOXP3 is a prerequisite for this suppressive activity, ultimately leading to tumor immune evasion/escape $(12,13)$. Additionally, patients with an altered expression or function of FOXP3 can develop serious autoimmune diseases and cancers $(14,15)$.FOXP3, a member of the forkhead/winged-helix family of transcription factors, constitutively translocate into the nucleus where it binds to specific sequences of DNA to regulate the transcription of its target genes $(16,17)$. Although FOXP3 protein expression was considered to be restricted to lymphocytes, recently it has been reported to be expressed in various human malignancies, such as pancreatic, lung, colon, breast, ovarian, prostate cancers, hepatocellular carcinoma, and melanoma (18-28). FOXP3 has been also associated with an unfavorable disease course $(24,25,27)$ and identified as an independent prognostic factor and a marker of tumor progression and metastasis (29-33). Indeed, numerous studies have 
demonstrated that metastases and poor clinical response of melanoma are closely related to the large number of Tregs and high FOXP3 expression (27,34-36).

Multiple signaling pathways, including NOTCH and transforming growth factor- $\beta$ (TGF- $\beta /$ Smad), are closely associated with FOXP3 transcription (37-41). NOTCH signaling regulates essential cell processes, such as stem cell self-renewal, proliferation, differentiation and apoptosis (42-44). Previous experimental data have shown that aberrant NOTCH signaling may lead to cancer, although its effect greatly depends on tissue type and interaction with other signaling pathways $(45,46)$. Activation of the NOTCH receptor is triggered by its interaction with NOTCH ligands (Delta-like 1, 3, 4; Jagged-1,2) present on adjacent cells (47). Upon ligand binding, the NOTCH intracellular domain (NICD) is proteolytically cleaved and translocated into the nucleus where it interacts with its corresponding co-activators to promote the transcription of downstream target genes $(48,49)$. Dysregulated NOTCH signaling has been involved in the development and progression of many types of cancer (50-56). Findings have shown that the upregulation of NOTCH signaling may play a role in melanoma cells transformation and progression (50-62,33).

In addition to NOTCH, TGF- $\beta$ is known as a double-edged sword during cancer progression, being a tumor suppressor or a tumor promoter, depending on the context of signal activation $(63-65)$.

TGF- $\beta$ is a pleiotropic cytokine that negatively regulates the activity of immune cells, playing an important role in the control of T-cell functions, growth and differentiation (66). Moreover, TGF- $\beta$ signaling is involved in Tregs differentiation being required for their in vivo expansion and immunosuppressive capacity (67). In vitro studies have shown that TGF- $\beta$ may trigger FOXP3 expression in CD $4^{+}$ $\mathrm{CD}^{2} 5^{-}$naive $\mathrm{T}$ cells, switching them towards a $\mathrm{CD} 4^{+} \mathrm{CD} 25^{+}$ regulatory phenotype, probably through activation of Smads, which results in a positive autoregulatory loop $(68,69)$. Furthermore, all human tumors overproduce TGF- $\beta$, whose autocrine and paracrine actions promote tumor cell invasiveness and metastasis (70-74). TGF- $\beta$ signaling can synergize with NOTCH in many processes (75-77). Previous findings have identified the bidirectional regulation of $\mathrm{NOTCH}$ and $T G F-\beta$, through different context-dependent mechanisms and a functional synergism in the regulation of hairy and enhancer of split 1 (HES1), a direct target of the NOTCH signal, has been demonstrated (78-80). It has been previously shown that the induction of FOXP3-Tregs is cooperatively regulated by NOTCH signaling and TGF- $\beta(76,79,81-83)$.

Few reports have shown the association between FOXP3 and NOTCH in cancers $(84,85)$ and the cross-talk between them is unexplored in melanoma. Since TGF- $\beta$ and NOTCH are involved in the regulation of the FOXP3 gene transcription, we investigated, in melanoma in vitro models, the mechanisms of TGF- $\beta 1$-induced FOXP3 gene expression in relation to NOTCH signaling inactivation. For this reason, we have used a synthetic tripeptide aldehyde containing $\gamma$-secretase inhibitor (GSI), a pharmacological agent known to block NOTCH processing and activation through the inhibition of proteolysis and translocation of NIDC to the nucleus (86).

\section{Materials and methods}

Human melanoma cell lines and culture conditions. Human epithelial melanocytes (NHEM) were purchased from Lonza (Lonza Group, Ltd., Basel, Switzerland), cultured in Melanocyte Growth Medium (Lonza Group, Ltd.) and used as controls. WM35 (from primary lesion), A375 and A2058 (from metastatic lesion) melanoma cell lines, a kind gift from V. Russo (Tumor Targeting Research Unit, San Raffaele Scientific Institute, Milano, Italy) were cultured in RPMI-1640 medium (Gibco; Life Technologies, Inc., Monza, Italy), supplemented with $2 \mathrm{mmol} / \mathrm{l} \mathrm{L}$-glutamine, $100 \mathrm{IU}$ penicillin, $100 \mu \mathrm{g} / \mathrm{ml}$ streptomycin, $10 \%$ of heat-inactivated fetal calf serum (Gibco; Life Technologies, Inc.) and maintained under an atmosphere of $5 \% \mathrm{CO}_{2}$ at $37^{\circ} \mathrm{C}$. For the western blot analysis, reverse transcription-quantitative polymerase chain reaction (RT-qPCR) and immunocytochemical analysis (ICC), 70-80\% confluent cultures were used.

Immunocytochemical analysis. A total of $1 \times 10^{5}$ cells (WM35, A375 and A2058) were grown on glass slides. Cells were washed in phosphate-buffered saline (PBS) and fixed with 4\% paraformaldehyde, $\mathrm{pH} 7.4$ for $20 \mathrm{~min}$ at room temperature. The cells were permeabilized with $0.5 \%$ Triton X-100 for 4 min and after washing in PBS were treated with $1 \%$ BSA to block non-specific binding sites. FOXP3 immunodetection was performed using a primary antibody anti-FOXP3 (1:100 dilution; ThermoFisher Scientific, eBioscience, Inc., San Diego, USA) for $2 \mathrm{~h}$ at room temperature, revealed using the Immuno Cruz Staining System (Santa Cruz Biotechnology, Inc, Santa Cruz, CA, USA). The cells were counterstained with hematoxylin for $30 \mathrm{sec}$. Appropriate positive and negative controls were carried out.

$R N A$ extraction and $R T-q P C R$. Total RNA was extracted from WM35, A375 and A2058 cell lines stimulate or not with TGF- $\beta 1$ using the Micro-to-Midi total RNA purification system (Invitrogen; Thermo Fisher Scientific, Inc., Waltham, MA, USA) according to the manufacturer's instructions. RNA was reverse transcribed into cDNA using the SuperScript III First-Strand Synthesis system (Invitrogen; Thermo Fisher Scientific, Inc.) according to the manufacturer's instructions.

mRNA expression was measured using SYBR-Green RT-qPCR using the Rotor-Gene Q thermal cycler (Qiagen, Inc., Valencia, CA, USA).

Amplification reactions were performed using primers specific for FOXP3 (forward, 5'-CACAACATGCGACCCC CTTTCACC-3' and reverse, 5'-AGGTTGTGGCGGAT GGCGTTCTTC-3'), NOTCH1 and HES1 (QuantiTect ${ }^{\circledR}$ Primer Assay; Qiagen, Inc.). The PCR reaction was carried out in $25 \mu \mathrm{l}$ buffer, containing $50 \mathrm{ng}$ cDNA, $1 \mu \mathrm{M}$ of each primer and 12.5 $\mu \mathrm{l} 2 \mathrm{X}$ RotorGene SYBR-Green PCR Master Mix (Qiagen, Inc.). The thermal cycling conditions were as follows: denaturation at $95^{\circ} \mathrm{C}$ for $5 \mathrm{~min}$, followed by 40 cycles of denaturation for $10 \mathrm{sec}$ at $95^{\circ} \mathrm{C}$ and annealing and extension for $15 \mathrm{sec}$ at $60^{\circ} \mathrm{C}$. As housekeeping gene, glyceraldehyde 3-phosphate dehydrogenase (GAPDH; QuantiTect Primer assay; Qiagen, Inc.) was used. Transcripts quantification was carried out utilizing the software supplied with Rotor-Gene Q. The experiments were repeated three times. 

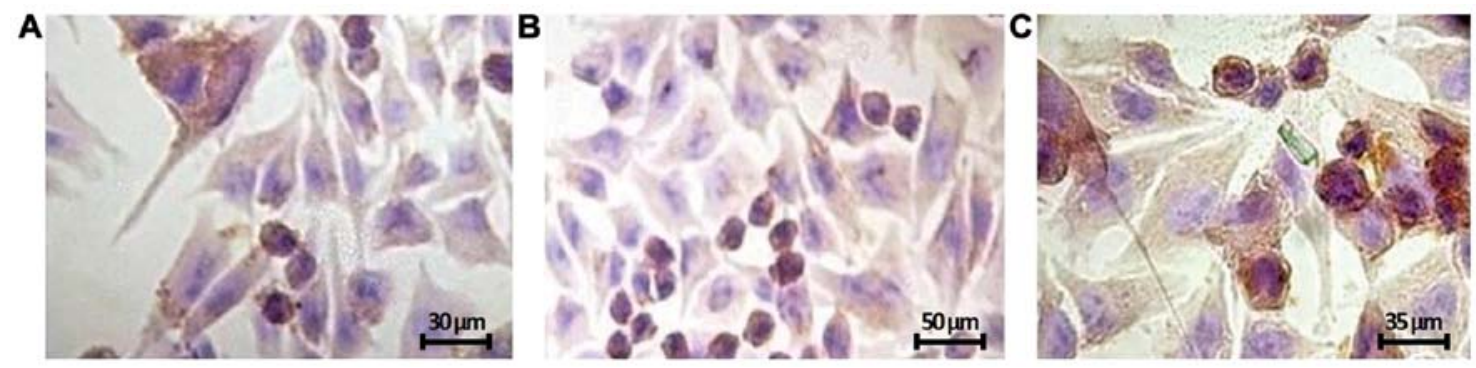

Figure 1. Immunocytochemical analysis of FOXP3 expression in the melanoma cell lines. (A) A moderate nuclear/cytoplamic Foxp3 staining in WM35 was observed. (B and C) Moderate to strong nuclear/cytoplasmic staining of FOXP3 protein is detected in the A375 and A2058 cell lines. FOXP3, forkhead box protein 3 .

Protein extraction and western blot analysis. Cells were lysed in RIPA buffer (Thermo Fisher Scientific, Inc.) in the presence of $1 \mathrm{mM}$ of the protease inhibitor phenylmethylsulfonyl fluoride (PMSF; Thermo Fisher Scientific, Inc.) and incubated on ice for 30 min. Protein concentration was determined by Bradford assay, using the Quick Start Bradford kit (Bio-Rad Laboratories, Inc., Hercules, CA, USA). Total proteins were fractionated using SDS-PAGE (Invitrogen; ThermoFisherScientific,Inc.)andtransferredontonitrocellulose membranes (Trans-Blot Transfer Medium Pure Nitrocellulose Membrane $0.45 \mu \mathrm{m}$; Bio-Rad Laboratories, Inc.). Membranes were blocked with 5\% non-fat dried milk in TBS buffer containing (20 mM Tris, $500 \mathrm{mM} \mathrm{NaCl}$, and $0.05 \%$ Tween-20) and incubated overnight with the appropriate primary monoclonal antibody: Anti-NOTCH1-NICD (dilution 1:1,000; cat. no. 14-5785-81; ThermoFisher Scientific, eBioscience, Inc.), anti-FOXP3 (dilution 1:1,000; cat. no. 14-5773-80; ThermoFisher Scientific, eBioscience, Inc.), anti-HES1 (dilution 1:500; cat. no. AB5702 ; EMD Millipore, Billerica, MA, USA), anti-Smad3 and phospho-Smad3 (dilution 1:1,000; cat. nos. 9513S and 9520S, respectively; Cell Signaling Technology, Inc., Danvers, MA, USA). Horseradish peroxidase-conjugated anti-rabbit or anti-goat $\operatorname{IgG}$ was used as the secondary antibody and the protein bands were detected using the enhanced chemiluminescence detection system (ECL detection system; Bio-Rad Laboratories, Inc.). Protein levels were determined using laser densitometry and normalized to GAPDH (Calbiochem; Merck KGaA, Darmstadt, Germany) levels in each sample.

GSI and TGF- $\beta$ treatment. A synthetic tripeptide aldehyde inhibitor, GSI (Calbiochem; Merck KGaA), a potent GSI, was used to block NOTCH1-mediated signal transduction in melanoma cell lines. Cells in the logarithmic growth phase were seeded at densities of $4 \times 10^{5}$ cells/ml (WM35) and $2 \times 10^{5}$ cells/ml (A375 and A2058) and treated or not with GSI, at different concentrations $(5,10$ and $20 \mu \mathrm{M})$ for the desired period of time. The cells were then stimulated with recombinant human (rh)TGF- $\beta$ ( $5 \mathrm{ng} / \mathrm{ml}$; Gibco; Life Technologies, Inc.) for $48 \mathrm{~h}$. Control cells were treated with an equal volume of dimethyl sulfoxide (DMSO). Expression of FOXP3 and NOTCH signaling, cell growth proliferation and inhibition of melanoma cell lines were analyzed.

Cell proliferation-cytotoxicity assay. GSI effects on cell proliferation was measured using the [3-(4,5-dimethyl- thiazol-2-yl)-2,5-diphenyl tetrazolium bromide (MTT); Sigma-Aldrich, St. Louis, MO, USA] colorimetric assay as described by Cardile et al (87). In brief, melanoma cell lines $\left(1-2 \times 10^{4}\right.$ cells/well) were grown overnight in 24 -well plates and then treated with vehicle alone or different concentrations of GSI. After 24, 48 and $72 \mathrm{~h}$ treatment, the cells were incubated with $20 \mu \mathrm{l}$ of $0.5 \%$ MTT in PBS for $4 \mathrm{~h}$ at $37^{\circ} \mathrm{C}$ in a humidified $95 \%$ air $/ 5 \% \mathrm{CO}_{2}$; supernatant was removed and $100 \mu \mathrm{l}$ of DMSO was added to each well. Optical density was measured at $550 \mathrm{~nm}$ (Titertek Multiskan; DAS). Cell viability was expressed as a percentage of treated cells with respect to appropriate controls. Trypan blue dye exclusion assay was used to evaluate the percentage of dead cells with respect to the total number of cells.

Statistical analysis. Differences between TGF- $\beta 1$ stimulated or not were compared by Student's t-test. Differences among multiple groups were compared by analysis of variance (ANOVA test) and a post hoc test for multiple comparisons (Tukey's test). Data are presented as mean \pm SD. P-values $<0.05$ were considered statistically significant.

\section{Results}

Upregulation of FOXP3 expression on human melanoma cell lines by TGF- $\beta 1$. We used different approaches to examine the baseline gene expression of FOXP3 as well as the protein levels, in human melanoma cell lines at different stages, primary (WM35) versus metastatic (A375 and A2058) cells. Normal human epidermal melanocytes (NHEM) were used as a control.

First, we observed by immunocytochemistry that FOXP3 was mainly localized in the nucleus and, was less evident, in the perinuclear region and cytoplasm. Moreover, the three melanoma cell lines showed different staining intensity, being the A2058 cell lines that were mostly expressed (Fig. 1), while NHEM FOXP3 staining was undetectable (data not shown).

Next, we examined the relative mRNA level of FOXP3 in WM35, A375 and A2058 melanoma cells. As expected, FOXP3 transcriptional levels, assessed by RT-qPCR, were higher in A2058 cells compared to A375 and WM35 cells, and very low in NHEM (Fig. 2A). In accordance with the RT-qPCR data, western blot analysis revealed that FOXP3 protein level expression was higher in A2058 compared to A375 and WM35 cells, whereas NHEM cells had a very weak expression (Fig. 2B). Moreover, since TGF- $\beta 1$ 
A

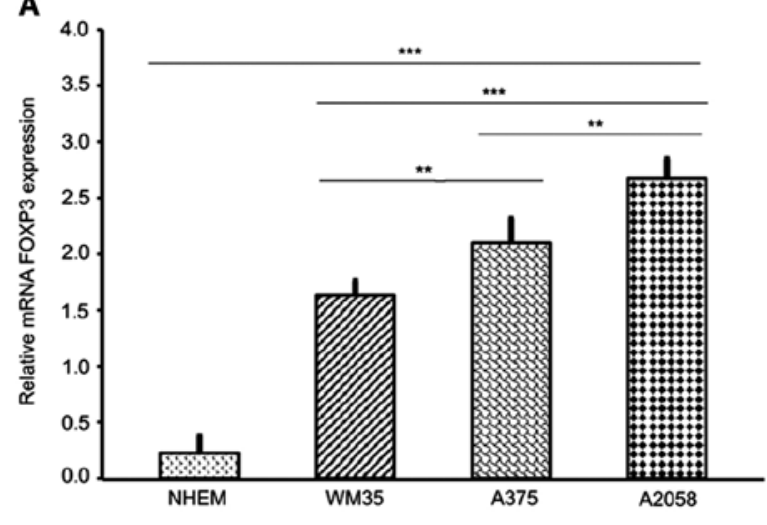

B

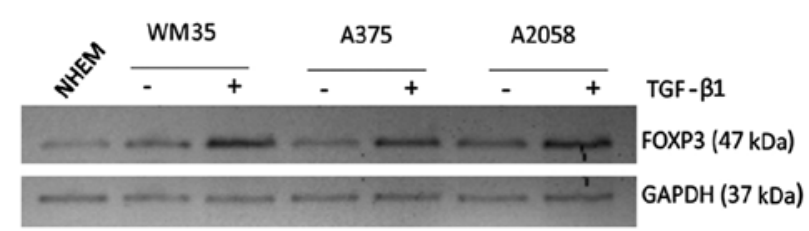

C

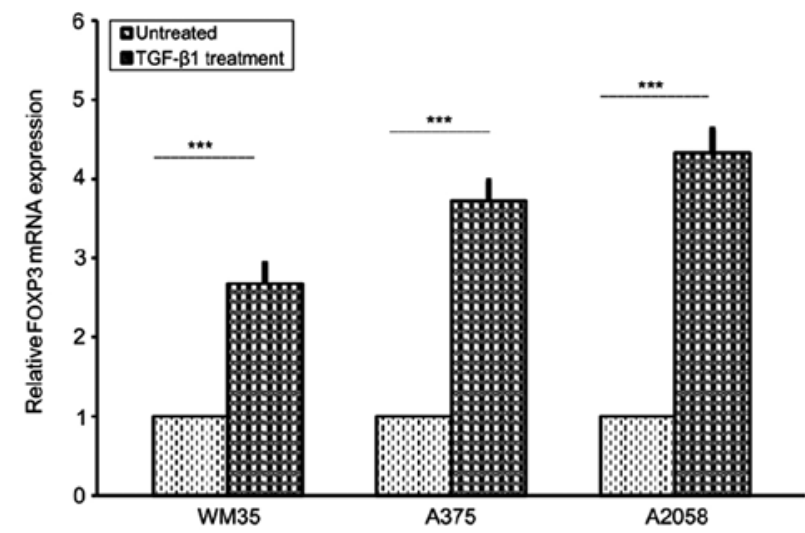

Figure 2. FOXP3 expression in human melanoma cell lines at different stages. (A) RT-qPCR of FOXP3 in melanocytes (NHEM), primary (WM35) and metastatic (A375 and A2058) melanoma cells. The melanoma cell lines expressed FOXP3 mRNA. Melanocytes served as a control. A375 and A2058 cells showed the highest levels of FOXP3 gene expression. (B and C) Effect of TGF $3-1$ treatment on protein and FOXP3 mRNA levels in melanoma cell lines. Treatment with rhTGF- $\beta 1(5 \mathrm{ng} / \mathrm{ml})$ for $48 \mathrm{~h}$ induced a higher increase of FOXP3 mRNA and their own protein levels in WM35, A375 and A2058 melanoma cells. As an internal control, GAPDH was used for normalization. Data are shown as mean $\pm \mathrm{SD}$ of three independent experiments. The comparison of multiple groups was performed by ANOVA and Tukey's test. High significance $\left({ }^{* * *} \mathrm{P}<0.0001\right)$ was found between TGF- $\beta 1$ stimulated or not in the three melanoma lines (Student's t-test). FOXP3, forkhead box protein 3; RT-qPCR, reverse transcription-quantitativepolymerase chain reaction; NHEM, normal human epidermal melanocytes; TGF- $\beta$, transforming growth factor- $\beta$; rh, recombinant human; GAPDH, glyceraldehyde 3 -phosphate dehydrogenase.

regulates T-cell function through FOXP3 (69), we examined the effect of this cytokine on FOXP3 expression in melanoma cells. Stimulation with rhTGF- $\beta 1(5 \mathrm{ng} / \mathrm{ml})$ for $48 \mathrm{~h}$ significantly increased the mRNA expression of FOXP3, approximately of 1.68-, 2.74- and 3.3-fold in WM35, A375 and A2058 cells, respectively, compared to untreated cells (Fig. 2C). Shorter treatments did not induce any appreciable change in FOXP3 expression. Western blot analysis confirmed the upregulation of TGF- $\beta 1$-induced FOXP3 protein levels (Fig. 2B). Altogether, our results show a very high expression of the transcription factor FOXP3 in human metastatic melanoma cells, suggesting that FOXP 3 could be considered a biological marker of melanoma progression, probably contributing to metastasis, as described by other authors (29,34-36).

Modulation of FOXP3 expression through the NOTCH signaling pathway. It has been shown that NOTCH signaling may be involved in the activation of FOXP3 promoter $(39,85)$. To analyze the potential role of NOTCH in modulating the FOXP3 expression in melanoma cells, we used the GSI, a GSI, responsible for inhibition of NOTCH cleavage into the active NICD $(47,86)$.
First, we tested, by RT-qPCR, the efficacy of GSI in FOXP3 expression reduction. WM35, A375 and A2058 cells were treated with DMSO, as a control, or increasing concentrations of GSI $(5,10$ and $20 \mu \mathrm{M})$ for 24,48 and $72 \mathrm{~h}$. FOXP3 mRNA expression decreased in a concentration- and time-dependent manner in all cell lines (Fig. 3A and B). GSI in low doses $(5,10 \mu \mathrm{M})$ for 24 and $48 \mathrm{~h}$ did not show any significant modification of FOXP3 gene expression (data not shown). At 72 h (Fig. 3A), we found a FOXP3 mRNA reduction of 40.7, 52.9\%; 40.1, 62.2 and 53\%, 62.6\% in WM35, A375 and A2058 cells treated with $20 \mu \mathrm{M}$ GSI compared to low doses $(5,10 \mu \mathrm{M})$, respectively. Furthermore, at $20 \mu \mathrm{M}$ GSI, a modest reduction of FOXP3 mRNA was observed in the three melanoma cell lines at 24 and $48 \mathrm{~h}$, while a strong and significant reduction was observed at $72 \mathrm{~h}$ (Fig. 3B). Thus, $20 \mu \mathrm{M}$ GSI for $72 \mathrm{~h}$ was the proper concentration and time for treating melanoma cells. We also verified whether FOXP3 was regulated at the translation level. In agreement with the RT-qPCR data, we observed a decrease of FOXP3 protein levels, in a dose-dependent manner, in the three melanoma cell lines after $72 \mathrm{~h}$ of GSI treatment. Fig. 3C shows the protein levels in the WM35 cell line treated with 5, 10 and $20 \mu \mathrm{M}$ GSI at $72 \mathrm{~h}$. 
A

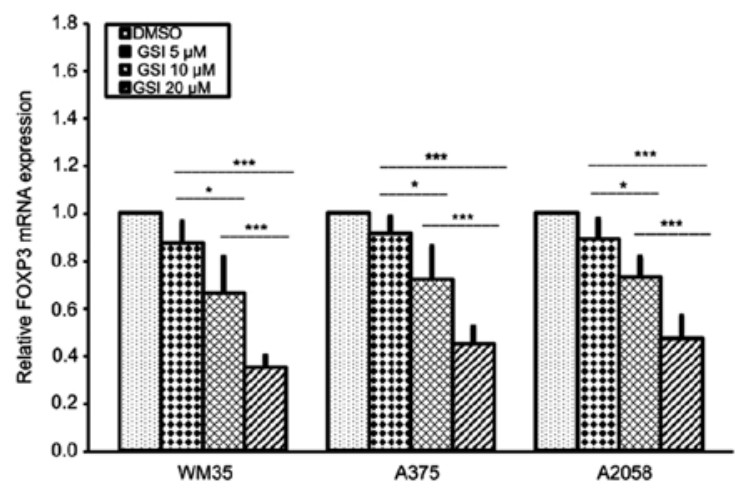

C

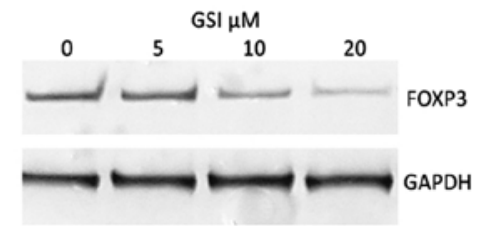

B

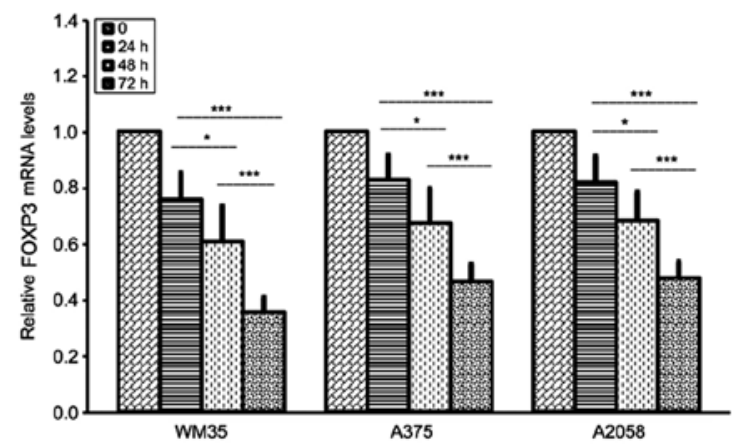

D

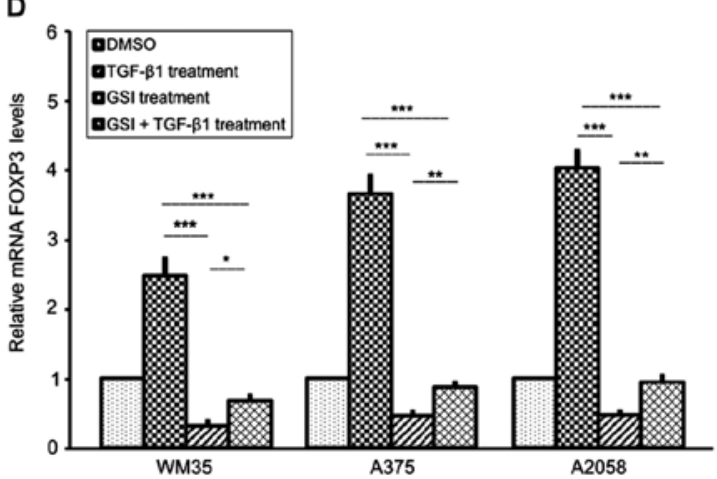

Figure 3. Effect of GSI on FOXP3 expression in melanoma cell lines. (A) Inhibition of FOXP3 mRNA is shown after 72 h of 5-, 10- and $20 \mu \mathrm{M}$ GSI treatment in melanoma cells. RT-qPCR shows that FOXP3 mRNA levels were downregulated in GSI-treated WM35, A375 and A2058 melanoma cells in a dose-dependent manner. Maximum inhibition of FOXP3 was observed at $20 \mu \mathrm{M}$ of GSI. (B) Inhibition of FOXP3 mRNA after 24, 48 and $72 \mathrm{~h}$ with $20 \mu \mathrm{M} / \mathrm{GSI}$ treatment in WM35, A375 and A2058 melanoma cell lines. A statistically significant time-dependent decrease in FOXP3 mRNA level was observed in each melanoma cell line. (C) Inhibition of FOXP3 protein expression after $72 \mathrm{~h}$ of 5-, 10- and $20 \mu \mathrm{M}$ GSI treatment in WM35 melanoma cells. Western blot analysis showed that the protein levels of FOXP3 were downregulated in GSI-treated WM35 cells in a dose-dependent manner. GAPDH expression was used as a loading control. (D and E) Effect of GSI/TGF- $\beta 1$ treatment on FOXP3 mRNA and protein expression in melanoma cell lines. Inhibition of FOXP3 mRNA and protein levels are shown after $72 \mathrm{~h}$ of GSI treatment in WM35, A375 and A2058 melanoma cells. In vitro GSI treatment downregulated TGF- $\beta 1$-induced FOXP3 mRNA and protein levels in all the melanoma cell lines. As an internal control, GAPDH was used for normalization. Data are shown as mean \pm SD of three independent experiments. The comparison of mRNA FOXP3 expression in multiple groups was performed by ANOVA and Tukey's test. GSI, $\gamma$-secretase inhibitor; FOXP3, forkhead box protein 3; TGF- $\beta$, transforming growth factor- $\beta$; GAPDH, glyceraldehyde 3 -phosphate dehydrogenase. ${ }^{*} \mathrm{P}<0.01 ;{ }^{* * *} \mathrm{P}<0.001 ;{ }^{* * *} \mathrm{P}<0.0001$.

To validate the possible relationship between NOTCH1/ TGF- $\beta 1$ in regulating FOXP3 expression, we also examined whether GSI, a NOTCH signaling inhibitor, influenced the TGF- $\beta 1$-dependent FOXP3 upregulation. WM35, A375 and A2058 cell lines were pre-treated overnight with $20 \mu \mathrm{M}$ GSI, to block NOTCH activation, using an equal volume of DMSO as control, and the cells were subsequently stimulated with rhTGF- $\beta 1$ for $48 \mathrm{~h}$. Fig. 3D shows that $20 \mu \mathrm{M}$ GSI significantly decreased FOXP3 mRNA levels in WM35, A375 and A2058 cell lines treated with TGF- $\beta 1$, although the downregulation did not reach the levels observed in cells treated with GSI alone. Data were confirmed by western blot analysis (Fig. 3E).

Taken together, these data indicate that upregulation of FOXP3 by TGF- $\beta 1$ may require input from the NOTCH signaling pathway.

Activation of NOTCH1 pathway by TGF- $\beta 1$ in human melanoma cell lines. Since TGF- $\beta 1$ upregulates FOXP3 levels and in considering that NOTCH/TGF- $\beta$ signaling is involved in the tumorigenic process of cancers $(50,65,88)$, including melanoma $(62,89,90)$, we investigated whether TGF- $\beta 1$ was able to affect the NOTCH signaling in melanoma cell lines. We tested $\mathrm{NOTCH}{ }^{\mathrm{NICD}}$ and the NOTCH-specific target gene HES1 expression in WM35, A375, A2058 and NHEM cells by RT-qPCR and western blot analysis. Generally, NICD levels reflect the activation status of NOTCH signaling.

Our results showed that NOTCH1 $1^{\text {NICD }}$ and HESI expression were significantly increased in the three melanoma cell lines compared to NHEM cells at both mRNA and protein levels (Fig. 4A and D). This increase was more evident in WM35 compared to A375 and A2058 cells. Next, to confirm the association between TGF- $\beta 1$ and NOTCH1, we stimulated WM35, A375 and A2058 cells with rhTGF- $\beta 1(5 \mathrm{ng} / \mathrm{ml})$ for $48 \mathrm{~h}$. We found higher mRNA and protein levels of NOTCH1 ${ }^{\mathrm{NICD}}$ and HES1, in WM35, A375 and A2058 cells, after stimulation with rhTGF- $\beta 1$, compared to untreated cells (Fig. 4B-D), confirming earlier studies carried out in other cancer types $(78,79,88,91)$.

GSI prevents TGF- $\beta 1$-dependent NOTCHI activation pathway. In parallel, we explored whether NOTCH signaling inhibition could prejudice NOTCH/TGF- $\beta$ axis. Western blot analysis revealed that NOTCH-1 protein and its downstream effector HESl were downregulated in GSI-treated melanoma 
A

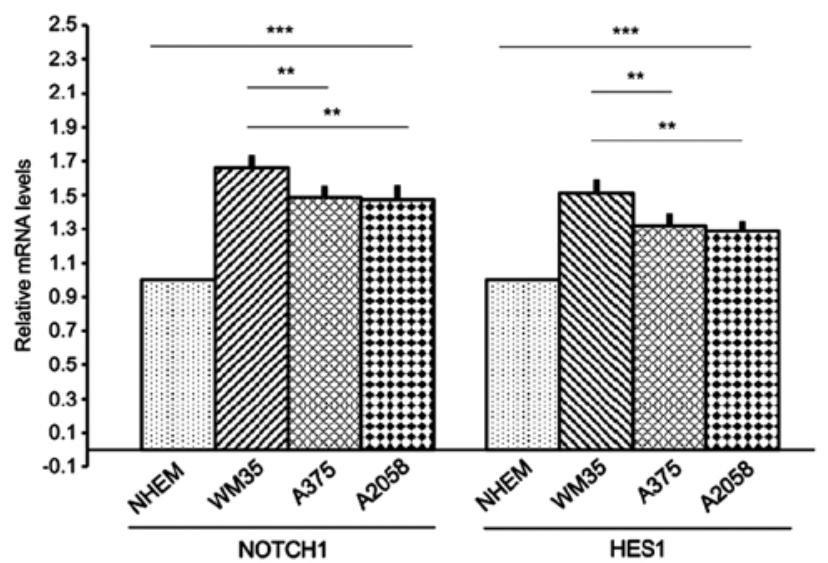

C

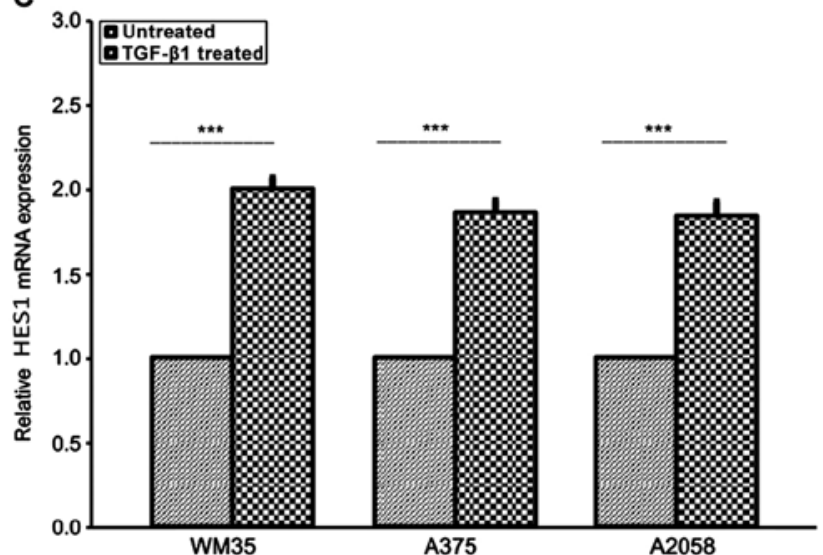

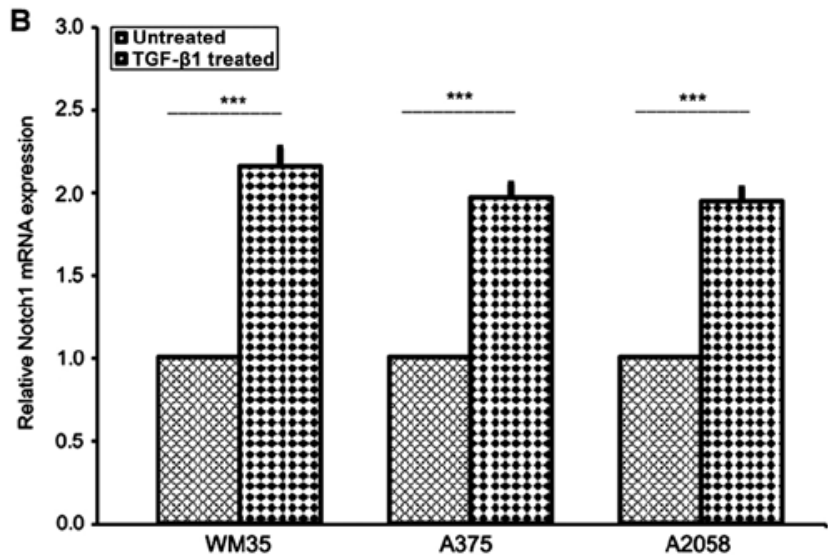

D

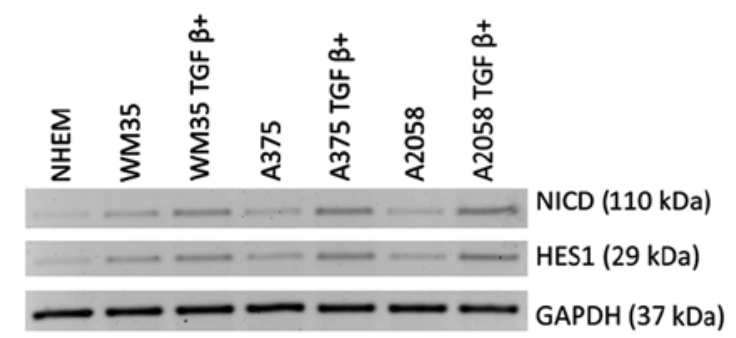

Figure 4. Expression of NOTCH1 ${ }^{\mathrm{NICD}}$ and NOTCH-specific target gene HES1 in melanoma cell lines. (A) mRNA of NOTCH1 ${ }^{\mathrm{NICD}}$ and HES1 was measured by RT-qPCR in NHEM, WM35 and A375 and A2058 melanoma cells. Melanocytes served as the control. WM35 showed a higher level of NOTCH1 ${ }^{\text {NICD }}$ mRNA and HES1 mRNA than A375 and A2058 cells. (B) Protein level of NOTCH1 ${ }^{\mathrm{NICD}}$ and HES1 was measured by western blot analysis in WM35, A375 and A2058 melanoma cell lines. All of the melanoma cell lines positively expressed NOTCH1 ${ }^{\mathrm{NICD}}$ and HES1. (B-D) Effect of TGF $3-1$ treatment on NOTCH1 ${ }^{\mathrm{NICD}}$, HES1 mRNA and protein levels in melanoma cell lines. Treatment with rhTGF- $\beta 1(5 \mathrm{ng} / \mathrm{ml})$ for $48 \mathrm{~h}$ induced a higher increase of NOTCH1 ${ }^{\mathrm{NICD}}$ and HES1 mRNA and their own protein levels in WM35, A375 and A2058 melanoma cells. As an internal control, GAPDH was used for normalization. Data are shown as mean \pm SD of three independent experiments. The comparison of mRNA NOTCH-1 and HES1 expression in multiple groups was performed by ANOVA and Tukey's test. HES1, hairy and enhancer of split 1 ; RT-qPCR, reverse transcription-quantitative polymerase chain reaction; TGF- $\beta$, transforming growth factor- $\beta$; rh, recombinant human; GAPDH, glyceraldehyde 3-phosphate dehydrogenase. ${ }^{* *} \mathrm{P}<0.001 ;{ }^{* * *} \mathrm{P}<0.0001$.
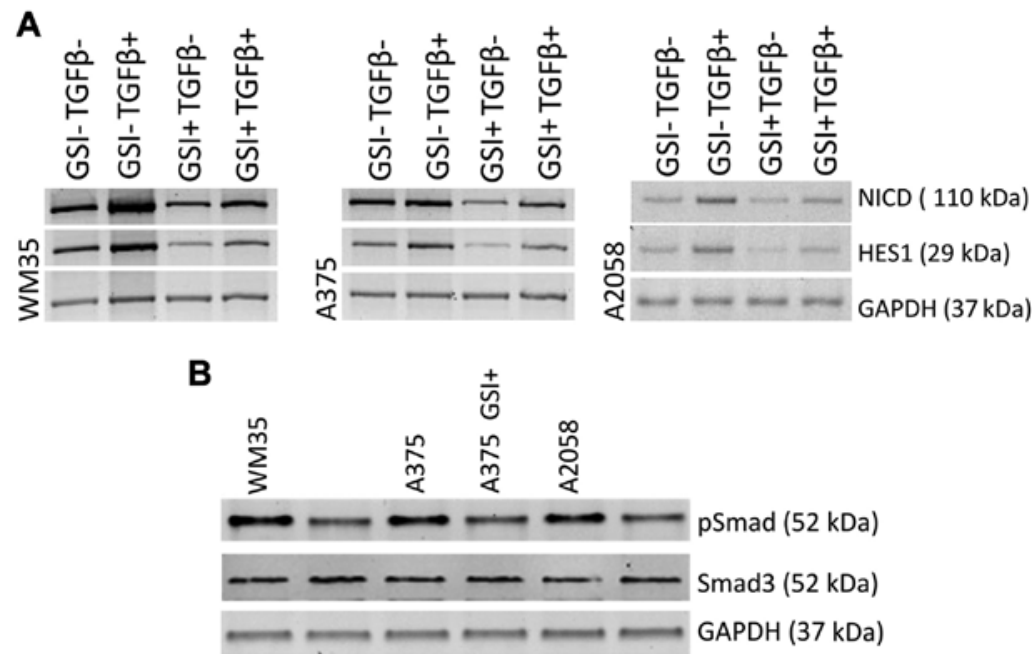

Figure 5. GSI effect on NOTCH1 $1^{\text {NICD }}$, NOTCH-specific target gene HES1 expression and on TGF- $\beta /$ Smad signaling in melanoma cell lines. (A) Inhibition of NOTCH1 $1^{\text {NICD }}$ and NOTCH-specific target gene HES1 is illustrated after $72 \mathrm{~h}$ of $20 \mu \mathrm{M}$ GSI treatment in WM35, A375 and A2058 cells. Western blot analysis showed that GSI suppressed NOTCH1 ${ }^{\text {NICD }}$ and HES1 protein levels and downregulated TGF $\beta-1$ - induced NOTCH1 ${ }^{\text {NICD }}$, HES1 protein levels in melanoma cell lines. (B) GSI treatment consistently decreased pSMAD3 levels in all melanoma cell lines. GAPDH served as loading control. GSI, $\gamma$-secretase inhibitor; HES1, hairy and enhancer of split 1 ; TGF- $\beta$, transforming growth factor- $\beta$; pSMAD3, phosphorylated Smad3; GAPDH, glyceraldehyde 3-phosphate dehydrogenase. 

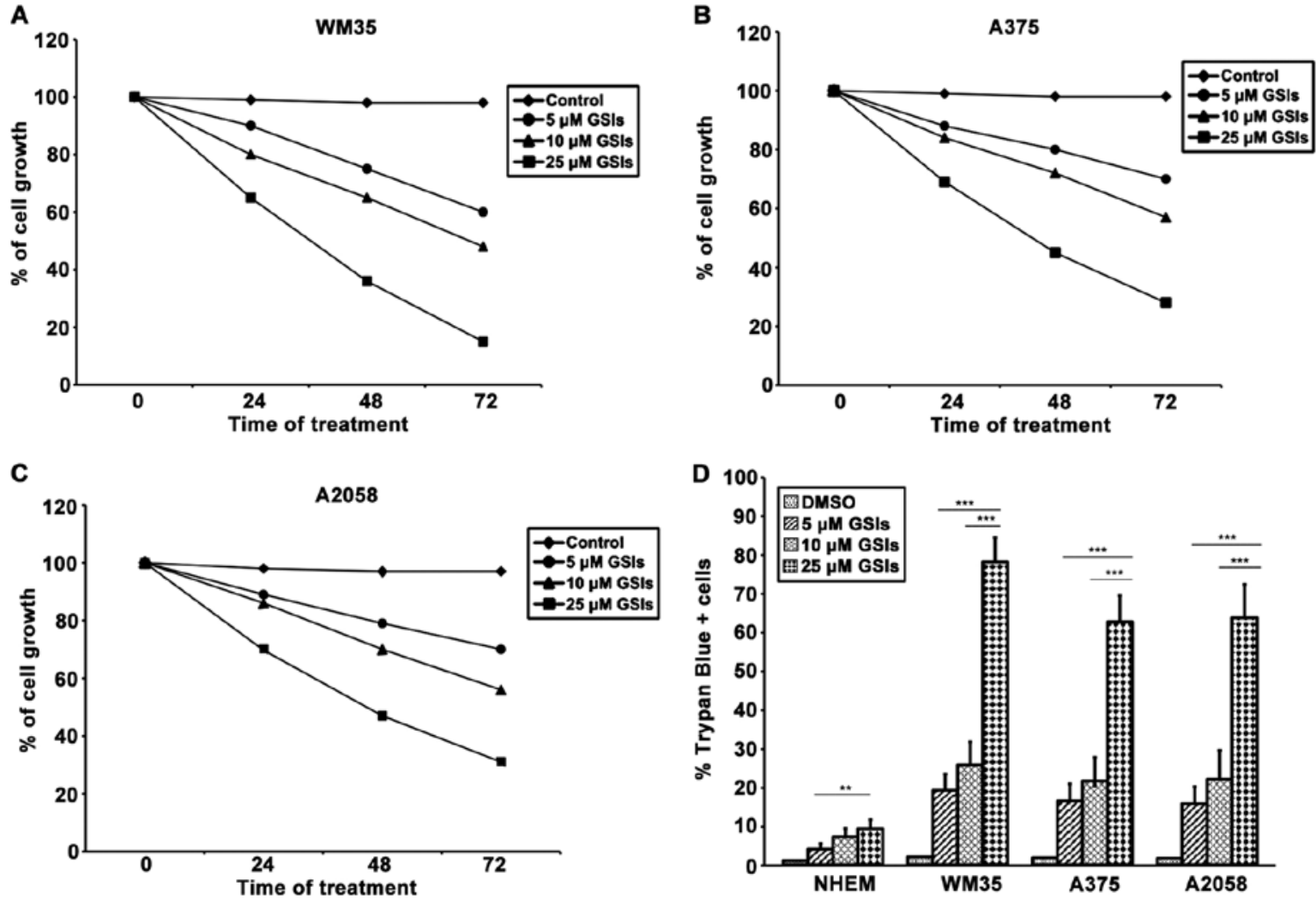

Figure 6. The effect of GSI on human melanoma cell line proliferation. (A) WM35, (B) A375 and (C) A2058 cell viability following 24-, 48- and 72-h GSI treatment. Cells were incubated with GSI at 5-, 10- and $20 \mu \mathrm{M}$. (A-C) GSI $20 \mu \mathrm{M}$ induces a significant decrease in cell proliferation. (D) Trypan blue exclusion test was performed in NHEM, WM35, A375 and A2058 cell lines. High cytotoxicity was observed with $20 \mu$ M GSI only in melanoma cell lines. Data are expressed as percentage of cell viability/cytotoxicity with respect to vehicle control as described in the Materials and methods. Results are the mean \pm SD from three separate experiments. The comparison of multiple groups was performed by ANOVA and Tukey's test. GSI, $\gamma$-secretase inhibitor; NHEM, normal human epidermal melanocytes. ${ }^{* * *} \mathrm{P}<0.0001$.

cells compared with vehicle control (Fig. 5A), confirming the ability of the drug to affect the NOTCH signaling pathway (61). Furthermore, to corroborate the effects of the NOTCH inhibition on TGF- $\beta 1$-induced NOTCH $1^{\text {NICD }}$ activation, WM35, A375 and A2058 cell lines were treated with TGF- $\beta 1$ alone or combined with GSI. Notably, we found that the upregulation of TGF- $\beta 1$-induced of the NOTCH $1^{\mathrm{NICD}}$ protein level was strongly decreased but not completely abolished by concomitant GSI treatment in WM35, A375 and A2058 cells. The same trend was evident for downstream target genes HESI (Fig. 5A).

Finally, to confirm the effect of NOTCH on TGF- $\beta /$ Smad signaling, we treated WM35, A375 and A2058 cells with and without GSI for $72 \mathrm{~h}$. Phosphorylated Smad3 (pSMAD3), a marker of constitutive TGF- $\beta 1$ receptor activity, was detected in WM35, A375 and A2058 cells; GSI treatment consistently decreased pSMAD3 levels in all melanoma cell lines (Fig. 5B), without interfere with the unphosphorylated Smad3 protein levels. These data highlighted the effect of NOTCH on $\mathrm{TGF} /$ Smad signaling in melanoma cell lines.

Cytotoxic and anti-proliferative effects of GSI on melanoma cells. To further investigate whether GSI could be an effective therapeutic target for melanoma, we first tested the effect of the drug on cell proliferation in WM35, A375 and A2058 after treatment to $0,5,10$ and $20 \mu \mathrm{M}$ of GSI for 24,48 and $72 \mathrm{~h}$. MTT analyses showed that melanoma cell lines, without GSI treatment, exhibited a linear growth up to confluence. In these experiments, DMSO, which was used as a vehicle control, did not affect cell growth, while GSI treatment induced a marked cell growth inhibition, in a dose- and time-dependent manner. The concentrations of 5 and $10 \mu \mathrm{M}$ showed a weak growth inhibition, but at $20 \mu \mathrm{M}$, GSI significantly inhibited proliferation at each incubation time for all the cell lines, the maximum inhibition was attained at $72 \mathrm{~h}$ (Fig. 6A-C). However, GSI effects were significantly greater in WM35 cells rather than in A375 and A2058; no difference was noted between A375 and A2058 cells. MTT assay did not discriminate if the decrease of proliferation rate was attributed to growth arrest or cell death, since both mechanisms induce a decrease in cell numbers and an apparent loss of viability. To establish this, a Trypan blue exclusion test was performed on melanoma cell lines. As shown in Fig. 6D, GSI exerted a significantly more toxic effect on the melanoma cells compared to DMSO. The cytotoxicity of GSI on WM35 cells was significantly higher than that of A375 and A2058 cells. GSI showed very low toxicity in normal melanocytes.

\section{Discussion}

Many studies have shown that FOXP3 is expressed not only by Tregs, but also in a variety of tumor cells, including melanoma $(18-20,25,27,28,33)$. Expression of FOXP3 by cancer cells may cause the inhibition of tumor directed T-cell responses and may favor tumor cells immune-evasion 
mechanisms $(22,23,27,30,31,33)$. By contrast, other studies have suggested that FOXP3 plays a critical role in suppressing the development of several types of tumors, such as ovarian, prostate and breast cancer, through the inhibition of cell proliferation, migration and invasion or by modulating the expression of oncogenes or tumor suppressor genes (29,91-93). Thus, the FOXP3 gene or protein exerts different functions in different types of tumors. In any case, the role of FOXP3 in carcinogenesis is intriguing and remain controversial.

Multiple signaling pathways, including $\mathrm{NOTCH}$ and TGF- $\beta /$ Smad pathways, are involved in FOXP3 transcription regulation $(17,37,38,41,76,83,95)$. Few studies have shown the association between NOTCH/FOXP3 in cancers $(84,85)$ and to the best of our knowledge there are no reports investigating directly the relationship between NOTCH/TGF- $\beta$ signaling and FOXP3 transcription factor in melanoma.

In the present study, we investigated the involvement of NOTCH/TGF- $\beta 1$ signaling pathways in regulating the FOXP3 transcription factor and demonstrated, for the first time, that FOXP3 expression was modulated by NOTCH/TGF- $\beta 1$ pathways in primary and metastatic melanoma cell lines. The subcellular localization of FOXP3 in human melanoma cell lines at different stages of cancer progression was studied by immunocytochemistry. Our results showed that the intensity of $F O X P 3$ expression in melanoma metastatic cells lines (A375 and A2058) was higher than that in primary melanoma cells (WM35), while FOXP3 staining was undetectable in melanocytes. These results underline that FOXP3 staining gradually increase from the primary to the metastatic melanoma cell lines.

This result suggested that FOXP3 expression may be associated with metastatic spread. These data partially confirm the study by Quaglino et al (32), which demonstrated a significant association between FOXP3 expression in primary melanomas and development of visceral metastases. Our study also showed an heterogeneous subcellular localization of FOXP3 mainly in the nucleus, less in cytoplasm and in perinuclear region. Metastatic melanoma cell lines exhibited strong FOXP3 positive staining in the nucleus and weak staining in the cytoplasm. Similar to our results, Brody et al (96) reported a nuclear FOXP3 expression in Tregs localized at the primary melanomas and at the interface of metastasis with the lymph node parenchyma. Chen et al (97) showed that activation of $\mathrm{CD}^{+}{ }^{+} \mathrm{CD} 25^{+}$Treg induced a shift in the subcellular localization of FOXP3 from a primarily cytoplasmic/perinuclear pattern, in most cells, to a nuclear pattern, suggesting that the change in the FOXP3 expression pattern may be a result of post-translational modifications. Similar results were obtained by Niu et al (27) and subcellular staining of FOXP3 was demonstrated in other types of cancer $(19-21,24)$ due to post-translational modification and types of cancer (97). However, the exact involvement of this variable expression of FOXP3 remains unclear.

Subsequently, we confirmed in vitro, by RT-qPCR and western blot analysis, FOXP3 expression in melanoma cell lines. Our study has revealed that $F O X P 3$ was strongly expressed in metastatic melanoma cell lines. A higher FOXP3 at mRNA and protein levels was more evident in the metastatic melanoma cell line A2058, compared to A375, cell lines derived from the dermis of a malignant melanoma. In addition,
FOXP3 expression was slightly lower in the primary melanoma cells (WM35), but was still significantly higher than that in the melanocytes.

This result suggests that $F O X P 3$ is a biological marker of melanoma progression and may contribute to metastasis. These results are particularly noteworthy and confirm those reported by other studies that associated high FOXP3 levels with metastasis in several tumors, including melanoma $(22,31,33,98,99)$.

Since the potential role of FOXP3 has been demonstrated in various cancer types on immune surveillance (20), we examined the effects of TGF- $\beta 1$ on the induction of FOXP3 in melanoma cell lines. We showed that TGF- $\beta 1$ treatment upregulated $F O X P 3$ expression at the transcriptional and post-translational level, more in A2058 and A373 cells than in WM35 cells.

Overall, our data strongly emphasize the role of TGF- $\beta 1$ and FOXP3 in promoting melanoma progression.

Melanoma is a type of highly immunogenic cancer and is a rich source of TGF- $\beta$ (65). It is possible that TGF- $\beta 1$, one of the many factors present in the tumor microenvironment, can induce FOXP3 and the regulatory activity in Treg cells $(27,28,68,69,100)$. FOXP3-expressing melanoma cells may have Treg-like activity, thus suppressing effector T-cell activity $(28,34)$. It is possible that FOXP3 immunosuppressive function in the FOXP3-driven metastatic process requires a crosstalk between tumor cells and the microenvironment (34).

It has been demonstrated that, for the majority of the Treg cells, FOXP3 expression is transient and its persistence is highly dependent on the TGF- $\beta$ exposure present in tumoral microenvironment (101).

The identification of regulatory mechanisms that potentially lead to a decreased expression of FOXP3 may offer insight into the control of tumor cell proliferation and progression in melanoma and provide new perspectives to develop potential therapeutic targets. Although numerous cell surface molecules could mediate this condition, we focused on NOTCH signaling because it was shown that NOTCH may be involved in the activation of FOXP3 promoter through RBP-J- and HES1-dependent mechanisms (39). In addition, emerging evidence indicated that TGF- $\beta 1$ and $\mathrm{NOTCH}$ act in concert to regulate the transcription of target genes (102-104). For example, TGF- $\beta 1$, through effector Smad3, and NOTCH ${ }^{\mathrm{NICD}}$ physically interact to coordinately regulate the transcription of Hesl and FOXP3 (76-79). Further findings have shown that the NOTCH ligand Jagged2 promotes Treg cell proliferation, leading to an increase in TGF- $\beta$ production (105).

NOTCH/TGF- $\beta 1$ pathways are important regulators of many fundamental processes of cancer cell biology, such as tumor growth, angiogenesis, invasion and tumor progression $(72,78,79,80,88,91,106,107)$.

Aberrant expression of TGF- $\beta 1$ and NOTCH pathway has been demonstrated previously in melanoma $(57,61,74,90,108)$.

In accordance with the above reported studies, we found that both the NOTCH ${ }^{\mathrm{NICD}}$ and Hes1 mRNA and protein levels were higher in primary melanoma (WM35) compared to metastatic melanoma cells (A375 and A2058). Moreover, TGF- $\beta 1$ treatment induced upregulation of $\mathrm{NOTCH}^{\mathrm{NICD}}$ and Hes1 in all the melanoma cell lines. The increase of Hes1 by TGF- $\beta 1$ 
is consistent with earlier studies, one of which demonstrated a cooperative interaction between Smad3 and NOTCH on CSL binding elements $(79,91,109)$. Hesl is the most well characterized target gene of $\mathrm{NOTCH}$, and its upregulated expression symbolizes the activated NOTCH signaling.

Consistent with our data, other reports have found that NOTCH signaling are upregulated in primary lesions of human malignant melanoma $(61,62,89)$.

This suggests that NOTCH signaling may be involved in melanomagenesis, by activating MAPK/PI3K/AKT signaling pathways, and corroborate the idea that it has less effect on metastatic cell lines, suggesting its primary function in early transformation events $(57,60,110)$. In contrast to oncogenetic role in melanoma, NOTCH pathway is downregulated in other cancers, including skin carcinoma (111-113). A recent study of Banerjee et al (114) showed that inhibition of NOTCH causes pathologic activation of liver stromal cells, promoting angiogenesis and growth of hepatic metastases. In a later study, Talora et al (115) showed that in HPV-positive cervical cancer cells, activated NOTCH causes growth suppression. The involvement of NOTCH in cancer development is complex, since NOTCH can function as an oncogene or a tumor suppressor depending on the tissue type, different cell context and on crosstalk with other signaling pathways $(45,46)$. Previous findings have shown that NOTCH signaling is largely regulated by $\gamma$-secretase activity, responsible for cleavage of NOTCH into its active intracellular transactivator NICD and for its translocation to the nucleus, where it induces the transcription of target genes $(47,86)$. Recently, there has been an increased interest in targeting the NOTCH pathway using GSIs as a new target therapy for those tumors with $\mathrm{NOTCH}$ activation $(86,116,117)$. Thus, when we treated the melanoma cell lines with the GSI, a strong effect on both growth inhibition and cellular death in WM35, A375 and A2058 cells was evident.

We have observed that low GSI doses did not induce cell growth inhibition or cell death, as shown by MTT assay and dye test. Instead, a high dose of GSI, led to inhibition of the proliferation rate, with concomitant induction of death of WM35, A375 and A2058 cells due to a strong NOTCH inhibition. Thus, the level of treatment operating on NOTCH signaling appears to be critical for the proliferation outcome.

The role of GSI in inhibiting the growth of melanoma cell lines is consistent with the previous findings in other cancers (110,118-120). Notably, some research has shown an opposite outcome; the overexpression of NOTCH signaling can inhibit the growth of cancer cells through induction of cell cycle arrest $(121,122)$.

Our results underline the role of NOTCH as an oncogene in melanoma because its downregulation causes inhibition of cell growth and induction of cellular death in all the melanoma cell lines.

Based on the data presented herein and in consideration that FOXP3 signaling may function as a potential oncogenic factor in melanoma $(28,32,33,99,123)$, we hypothesized that the pharmacological inhibition of NOTCH by GSI, could reduce the tumorigenic activity that $\mathrm{NOTCH}$ exerts through several signaling pathways in melanoma cells, such as FOXP3 pathways and TGF- $\beta / \mathrm{Smad} 3$ signaling.

Of note, we have found that GSI treatment strongly decreased FOXP3 expression at the transcriptional and translational level in WM35, A375 and A2058 cells in a dose- and time-dependent manner. Consistent with our results, prior studies have shown that blockade of the NOTCH1 inhibited FOXP3 expression and Treg suppressor function $(76,82,85,124)$. This finding emphasizes the role of NOTCH signaling in Treg differentiation and FOXP3 transcription. In addition, we found that GSI reduced the upregulation of TGF- $\beta 1$-mediated FOXP3 gene and protein in primary and metastatic melanoma cells. In this regard, it is interesting to note that various reports have shown cell-type specific effect of TGF- $\beta 1$, as a mediator of FOXP3 and NOTCH signaling pathways (76-78). In other cases, however, the NOTCH ${ }^{\text {NICD }}$ signaling blocks TGF- $\beta 1$ signaling by mutually interfering with the Smad3 (125-127). This emphasizes the complexity of the interaction between FOXP3 and NOTCH/TGF- $\beta$ signaling that may produce different signaling outcomes depending on other signaling pathways.

This study further confirms the functional integration between NOTCH and TGF- $\beta 1$ signaling pathways and underlines the synergistic effect of NOTCH on a subset of Smad3-inducible genes. We found that GSI markedly induced both a decreased level of $\mathrm{NOTCH}^{\mathrm{NICD}}$ protein, that of its downstream gene Hesl, and attenuated strongly the levels of TGF- $\beta 1$-induced NOTCH ${ }^{\mathrm{NICD}}$ and Hes 1 protein in WM35, A375 and A2058 melanoma cell lines. In addition, we detected that the downregulation of NOTCH ${ }^{\mathrm{NICD}}$ by GSI decreased the pSmad3 protein, a downstream transcription factor of TGF- $\beta 1$. $\mathrm{NOTCH}^{\mathrm{NICD}}$, not only interacts with pSmad3, facilitating its nuclear translocation $(91,128)$, but also remains bound with $\mathrm{pSmad} 3$ in the nucleus where they cooperatively upregulate the transcription factor FOXP3 $(76,81,129)$. Tone et al $(130)$, have demonstrated that the mechanism underlying TGF- $\beta$-driven of FOXP3 expression involves the induction of activated Smad3 (pSmad3), which acts as a powerful transcription factor for the FOXP3 gene.

Taken together, our results sustain the role of $\mathrm{NOTCH}$ signaling in mediating the FOXP3 expression in melanoma cells by a dual mechanism: direct modulation of $F O X P 3$ transcription and cooperative interaction with the TGF- $\beta 1$ pathway in the modulation of FOXP3 expression. Our data suggest a possible crosstalk between NOTCH1/TGF- $\beta 1$ and FOXP3 pathways in melanoma cells.

Moreover, our data show that NOTCH ${ }^{\mathrm{NICD}}$ activation has an effect on TGF- $\beta /$ Smad signaling and confirm that the NOTCH and TGF- $\beta 1$ pathways are intertwined to regulate FOXP3 transcription factor in melanoma cell lines. Nevertheless, future studies are needed to validate our data. In vivo experiments are required to explore the role of NOTCH/TGF- $\beta$ pathway in the regulation of FOXP3 transcription factor in melanoma.

Finally, this study may provide a double additional rationale for targeting the NOTCH and FOXP3 signaling pathways for treatment of melanoma.

Despite various advances on the comprehension of the signal transduction pathways that modulate FOXP3 transcriptional activity, there are still many uncertainties.

A growing body of evidence suggests a connection between FOXP3 and NOTCH/TGF- $\beta$ signaling pathways and their link with cancer recurrence, metastasis, and patient prognosis $(76,85)$. Taken together these studies highlight the need of a more detailed understanding of how the 
NOTCH/TGF- $\beta$ /FOXP3 signals interact with other pathways in order to design rationally oriented targeted therapy experiments and trials.

The problem of secondary resistance to targeted therapy is a common problem in oncology. Thus, the use of drugs specifically targeting NOTCH, such as GSI, combined with other drugs, either standard chemotherapeutic agents or selective pathway-specific inhibitors, such as TGF- $\beta 1$ or Braf inhibitors, could offer a potential strategy for therapeutic investigations in melanoma. Therefore, our study not only corroborated some of these findings, but also identified a novel interaction between NOTCH and TGF- $\beta 1$ in modulating FOXP3 expression in melanoma cells. Although further studies are needed to clarify the role and molecular mechanisms that govern the association between FOXP3 and NOTCH/TGF- $\beta$ signaling in the progression of melanoma, the current study provides new insight into the carcinogenesis of melanoma.

\section{Acknowledgements}

Not applicable.

\section{Funding}

This study was supported by the Italian League Against Cancer.

\section{Availability of data and materials}

All data and materials are available at the Department of Biomedical and Biotechnological Science of the University of Catania and the Department of Clinical and Experimental Medicine, Section of Dermatology of the University of Messina.

\section{Authors' contributions}

ES, VB, FDA and AR have performed all the experiments. GM and CG conceived the study and wrote the manuscript. DAS and AS have revised the final version of the manuscript. All authors have read and approved the final manuscript.

\section{Ethics approval and consent to participate}

Not applicable.

\section{Consent for publication}

All authors agree to publication.

\section{Competing interests}

DAS is the Editor-in-Chief for the journal, but had no personal involvement in the reviewing process, or any influence in terms of adjudicating on the final decision, for this article.

\section{References}

1. Buzaid AC: Management of metastatic cutaneous melanoma. Oncology (Williston Park) 18: 1443-1450, discussion 1457-1459, 2004.

2. La Porta CA: Mechanism of drug sensitivity and resistance in melanoma. Curr Cancer Drug Targets 9: 391-397, 2009.
3. Fava P, Astrua C, Chiarugi A, Crocetti E, Pimpinelli N, Fargnoli MC, Maurichi A, Rubegni P, Manganoni AM, Bottoni U, et al: Differences in clinicopathological features and distribution of risk factors in Italian melanoma patients. Dermatology 230: 256-262, 2015.

4. Maio M: Melanoma as a model tumour for immune-oncology. Ann Oncol 23 (Suppl 8): viii10-14, 2012.

5. Shrayer DP, Bogaars H, Wolf SF, Hearing VJ and Wanebo HJ: A new mouse model of experimental melanoma for vaccine and lymphokine therapy. Int J Oncol 13: 361-374, 1998.

6. Nakai N, Katoh N, Kitagawa T, Ueda E, Takenaka H and Kishimoto S: Immunoregulatory T cells in the peripheral blood of melanoma patients treated with melanoma antigen-pulsed mature monocyte-derived dendritic cell vaccination. J Dermatol Sci 54: 31-37, 2009.

7. Russo A, Ficili B, Candido S, Pezzino FM, Guarneri C, Biondi A, Travali S, McCubrey JA, Spandidos DA and Libra M: Emerging targeted therapies for melanoma treatment (Review). Int $\mathbf{J}$ Oncol 45: 516-524, 2014.

8. Nakamura K and Okuyama R: Immunotherapy for advanced melanoma: Current knowledge and future directions. J Dermatol Sci 83: 87-94, 2016.

9. Slingluff CL Jr, Chianese-Bullock KA, Bullock TN, Grosh WW, Mullins DW, Nichols L, Olson W, Petroni G, Smolkin M and Engelhard VH: Immunity to melanoma antigens: From self-tolerance to immunotherapy. Adv Immunol 90: 243-295, 2006.

10. Hori S, Nomura T and Sakaguchi S: Control of regulatory T cell development by the transcription factor Foxp3. Science 299: 1057-1061, 2003.

11. Ramsdell F: Foxp3 and natural regulatory T cells: Key to a cell lineage? Immunity 19: 165-168, 2003.

12. Sakaguchi S: Naturally arising $\mathrm{CD}^{+}+$regulatory t cells for immunologic self-tolerance and negative control of immune responses. Annu Rev Immunol 22: 531-562, 2004.

13. Takeuchi $\mathrm{Y}$ and Nishikawa $\mathrm{H}$ : Roles of regulatory $\mathrm{T}$ cells in cancer immunity. Int Immunol 28: 401-409, 2016.

14. Liu R, Li S, Yang WH and Wang L: IPEX syndrome, FOXP3 and cancer. J Syndr 1: 7, 2013.

15. Martin F, Ladoire S, Mignot G, Apetoh L and Ghiringhelli F: Human FOXP3 and cancer. Oncogene 29: 4121-4129, 2010.

16. Coffer PJ and Burgering BM: Forkhead-box transcription factors and their role in the immune system. Nat Rev Immunol 4: 889-899, 2004.

17. Shen $\mathrm{Z}$, Chen $\mathrm{L}$, Hao F and Wu J: Transcriptional regulation of Foxp3 gene: Multiple signal pathways on the road. Med Res Rev 29: 742-766, 2009.

18. Lu H: FOXP3 expression and prognosis: Role of both the tumor and T cells. J Clin Oncol 27: 1735-1736, 2009.

19. Hinz S, Pagerols-Raluy L, Oberg HH, Ammerpohl O, Grüssel S, Sipos B, Grützmann R, Pilarsky C, Ungefroren H, Saeger HD, et al: Foxp3 expression in pancreatic carcinoma cells as a novel mechanism of immune evasion in cancer. Cancer Res 67: 8344-8350, 2007.

20. Karanikas V, Speletas M, Zamanakou M, Kalala F, Loules G, Kerenidi T, Barda AK, Gourgoulianis KI and Germenis AE: Foxp3 expression in human cancer cells. J Transl Med 6: 19, 2008.

21. Wang WH, Jiang CL, Yan W, Zhang YH, Yang JT, Zhang C, Yan B, Zhang W, Han W, Wang JZ and Zhang YQ: FOXP3 expression and clinical characteristics of hepatocellular carcinoma. World J Gastroenterol 16: 5502-5509, 2010.

22. Fu HY, Li C, Yang W, Gai XD, Jia T, Lei YM and Li Y: FOXP3 and TLR4 protein expression are correlated in non-small cell lung cancer: Implications for tumor progression and escape. Acta Histochem 115: 151-157, 2013.

23. Kim M, Grimmig T, Grimm M, Lazariotou M, Meier E, Rosenwald A, Tsaur I, Blaheta R, Heemann U, Germer CT, et al: Expression of Foxp3 in colorectal cancer but not in Treg cells correlates with disease progression in patients with colorectal cancer. PLoS One 8: e53630, 2013.

24. Merlo A, Casalini P, Carcangiu ML, Malventano C, Triulzi T, Mènard S, Tagliabue E and Balsari A: FOXP3 expression and overall survival in breast cancer. J Clin Oncol 27: 1746-1752, 2009.

25. Wolf D, Wolf AM, Rumpold H, Fiegl H, Zeimet AG, Muller-Holzner E, Deibl M, Gastl G, Gunsilius E and Marth C: The expression of the regulatory $\mathrm{T}$ cell-specific forkhead box transcription factor FoxP3 is associated with poor prognosis in ovarian cancer. Clin Cancer Res 11: 8326-8331, 2005.

26. Kiniwa Y, Miyahara Y, Wang HY, Peng W, Peng G, Wheeler TM, Thompson TC, Old LJ and Wang RF: $\mathrm{CD}^{+}{ }^{+}$Foxp3 $3^{+}$regulatory $\mathrm{T}$ cells mediate immunosuppression in prostate cancer. Clin Cancer Res 13: 6947-6958, 2007. 
27. Niu J,Jiang C,LiC,Liu L,Li K, JianZ and Gao T: Foxp3 expression in melanoma cells as a possible mechanism of resistance to immune destruction. Cancer Immunol Immunother 60: 1109-1118, 2011.

28. Ebert LM, Tan BS, Browning J, Svobodova S, Russell SE, Kirkpatrick N, Gedye C, Moss D, Ng SP, MacGregor D, et al: The regulatory $\mathrm{T}$ cell-associated transcription factor FoxP3 is expressed by tumor cells. Cancer Res 68: 3001-3009, 2008.

29. Douglass S, Ali S, Meeson AP, Browell D and Kirby JA: The role of FOXP3 in the development and metastatic spread of breast cancer. Cancer Metastasis Rev 31: 843-854, 2012.

30. Zeng C, Yao Y, Jie W, Zhang M, Hu X, Zhao Y, Wang S, Yin J and Song Y: Up-regulation of Foxp3 participates in progression of cervical cancer. Cancer Immunol Immunother 62: 481-487, 2013.

31. Triulzi T, Tagliabue E, Balsari A and Casalini P: FOXP3 expression in tumor cells and implications for cancer progression. J Cell Physiol 228: 30-35, 2013.

32. Quaglino P, Osella-Abate S, Marenco F, Nardò T, Gado C, Novelli M, Savoia P and Bernengo MG: FoxP3 expression on melanoma cells is related to early visceral spreading in melanoma patients treated by electrochemotherapy. Pigment Cell Melanoma Res 24: 734-736, 2011.

33. Gerber AL, Münst A, Schlapbach C, Shafighi M, Kiermeir D, Hüsler R and Hunger RE: High expression of FOXP3 in primary melanoma is associated with tumour progression. Br J Dermatol 170 103-109, 2014.

34. Viguier M, Lemaître F, Verola O, Cho MS, Gorochov G, Dubertret L, Bachelez H, Kourilsky P and Ferradini L: Foxp3 expressing $\mathrm{CD} 4{ }^{+} \mathrm{CD} 25$ (high) regulatory $\mathrm{T}$ cells are overrepresented in human metastatic melanoma lymph nodes and inhibit the function of infiltrating T cells. J Immunol 173: 1444-1453, 2004.

35. Knol AC, Nguyen JM, Quéreux G, Brocard A, Khammari A and Dréno B: Prognostic value of tumor-infiltrating Foxp3 ${ }^{+}$T-cell subpopulations in metastatic melanoma. Exp Dermatol 20: 430-434, 2011.

36. Jandus C, Bioley G, Speiser DE and Romero P: Selective accumulation of differentiated FOXP3(+) CD4 (+) T cells in metastatic tumor lesions from melanoma patients compared to peripheral blood. Cancer Immunol Immunother 57: 1795-1805, 2008.

37. Zhang $\mathrm{L}$ and Zhao Y: The regulation of Foxp3 expression in regulatory $\mathrm{CD} 4(+) \mathrm{CD} 25(+) \mathrm{T}$ cells: Multiple pathways on the road. J Cell Physiol 211: 590-597, 2007.

38. Wang X, Liu Y, Dai L, Liu Q, Jia L, Wang H, An L, Jing X, Liu M, Li P and Cheng Z: Foxp3 downregulation in NSCLC mediates epithelial-mesenchymal transition via NF- $\mathrm{B}$ signaling. Oncol Rep 36: 2282-2288, 2016.

39. Ou-Yang HF, Zhang HW, Wu CG, Zhang P, Zhang J, Li JC, Hou LH, He F, Ti XY, Song LQ, et al: Notch signaling regulates the FOXP3 promoter through RBP-J- and Hes1-dependent mechanisms. Mol Cell Biochem 320: 109-114, 2009.

40. Maruyama T,Konkel JE,Zamarron BF and Chen W: The molecular mechanisms of Foxp3 gene regulation. Semin Immunol 23 . 418-423, 2011.

41. Uzdensky AB, Demyanenko SV and Bibov MY: Signal transduction in human cutaneous melanoma and target drugs. Curr Cancer Drug Targets 13: 843-866, 2013.

42. Liu J, Sato C, Cerletti M and Wagers A: Notch signaling in the regulation of stem cell self-renewal and differentiation. Curr Top Dev Biol 92: 367-409, 2010.

43. Artavanis-Tsakonas S, Rand MD and Lake RJ: Notch signaling: Cell fate control and signal integration in development. Science 284: 770-776, 1999.

44. Bray SJ: Notch signalling: A simple pathway becomes complex Nat Rev Mol Cell Biol 7: 678-689, 2006.

45. Radtke F and Raj K: The role of Notch in tumorigenesis: Oncogene or tumour suppressor? Nat Rev Cancer 3: 756-767, 2003.

46. Roy M, Pear WS and Aster JC: The multifaceted role of Notch in cancer. Curr Opin Genet Dev 17: 52-59, 2007.

47. Kopan R and Ilagan MX: The canonical Notch signaling pathway: Unfolding the activation mechanism. Cell 137: 216-233, 2009

48. Fortini ME: Notch signaling: The core pathway and its posttranslational regulation. Dev Cell 16: 633-647, 2009.

49. Schroeter EH, Kisslinger JA and Kopan R: Notch-1 signalling requires ligand-induced proteolytic release of intracellular domain. Nature 393: 382-386, 1998.

50. Koch U and Radtke F: Notch signaling in solid tumors. Curr Top Dev Biol 92: 411-455, 2010
51. Gao J, Dong Y, Zhang B, Xiong Y, Xu W, Cheng Y, Dai M, Yu Z, $\mathrm{Xu} \mathrm{H}$ and Zheng G: Notch1 activation contributes to tumor cell growth and proliferation in human hepatocellular carcinoma HepG2 and SMMC7721 cells. Int J Oncol 41: 1773-1781, 2012.

52. Bolós V, Mira E, Martínez-Poveda B, Luxán G, Cañamero M, Martínez-A C, Mañes S and de la Pompa JL: Notch activation stimulates migration of breast cancer cells and promotes tumor growth. Breast Cancer Res 15: R54, 2013.

53. Reedijk M, Odorcic S, Zhang H, Chetty R, Tennert C, Dickson BC, Lockwood G, Gallinger S and Egan SE: Activation of Notch signaling in human colon adenocarcinoma. Int J Oncol 33: 1223-1229, 2008

54. Yuan X, Wu H, Xu H, Han N, Chu Q, Yu S, Chen Y and Wu K: Meta-analysis reveals the correlation of Notch signaling with non-small cell lung cancer progression and prognosis. Sci Rep 5: 10338, 2015.

55. Hijioka H, Setoguchi T, Miyawaki A, Gao H, Ishida T, Komiya S and Nakamura N: Upregulation of Notch pathway molecules in oral squamous cell carcinoma. Int J Oncol 36: 817-822, 2010.

56. Ai Q, Ma X, Huang Q, Liu S, Shi T, Zhang C, Zhu M, Zhang Y, Wang B, Ni D, et al: High-level expression of Notch1 increased the risk of metastasis in T1 stage clear cell renal cell carcinoma. PLoS One 7: e35022, 2012.

57. Pinnix CC, Lee JT, Liu ZJ, McDaid R, Balint K, Beverly LJ, Brafford PA, Xiao M, Himes B, Zabierowski SE, et al: Active Notch1 confers a transformed phenotype to primary human melanocytes. Cancer Res 69: 5312-5320, 2009.

58. Howard JD, Moriarty WF, Park J, Riedy K, Panova IP, Chung CH, Suh KY, Levchenko A and Alani RM: Notch signaling mediates melanoma-endothelial cell communication and melanoma cell migration. Pigment Cell Melanoma Res 26: 697-707, 2013.

59. Müller CS: Notch signaling and malignant melanoma. Adv Exp Med Biol 727: 258-264, 2012

60. Liu ZJ, Xiao M, Balint K, Smalley KS, Brafford P, Qiu R, Pinnix CC, Li X and Herlyn M: Notch1 signaling promotes primary melanoma progression by activating mitogen-activated protein kinase/phosphatidylinositol 3-kinase-Akt pathways and up-regulating N-cadherin expression. Cancer Res 66: 4182-4190, 2006.

61. Balint K, Xiao M, Pinnix CC, Soma A, Veres I, Juhasz I, Brown EJ, Capobianco AJ, Herlyn M and Liu ZJ: Activation of Notch1 signaling is required for beta-catenin-mediated human primary melanoma progression. J Clin Invest 115: 3166-3176, 2005.

62. Massi D, Tarantini F, Franchi A, Paglierani M, Di Serio C, Pellerito S, Leoncini G, Cirino G, Geppetti P and Santucci M: Evidence for differential expression of Notch receptors and their ligands in melanocytic nevi and cutaneous malignant melanoma. Mod Pathol 19: 246-254, 2006.

63. Akhurst RJ and Derynck R: TGF-beta signaling in cancer - a double-edged sword. Trends Cell Biol 11: S44-S51, 2001.

64. Trapani JA: The dual adverse effects of TGF-beta secretion on tumor progression. Cancer Cell 8: 349-350, 2005.

65. Massagué J: TGFbeta in cancer. Cell 134: 215-230, 2008

66. Li MO, Wan YY, Sanjabi S, Robertson AK and Flavell RA: Transforming growth factor-beta regulation of immune responses. Annu Rev Immunol 24: 99-146, 2006.

67. Huber S, Schramm C, Lehr HA, Mann A, Schmitt S, Becker C, Protschka M, Galle PR, Neurath MF and Blessing M: Cutting edge: TGF-beta signaling is required for the in vivo expansion and immunosuppressive capacity of regulatory $\mathrm{CD} 4^{+} \mathrm{CD} 25^{+}$ T cells. J Immunol 173: 6526-6531, 2004.

68. Chen W, Jin W, Hardegen N, Lei KJ, Li L, Marinos N, McGrady G and Wahl SM: Conversion of peripheral $\mathrm{CD} 4^{+} \mathrm{CD} 25^{-}$naive $\mathrm{T}$ cells to $\mathrm{CD} 4{ }^{+} \mathrm{CD} 25^{+}$regulatory $\mathrm{T}$ cells by TGF-beta induction of transcription factor Foxp3. J Exp Med 198: 1875-1886, 2003

69. Pyzik $M$ and Piccirillo CA: TGF-beta1 modulates Foxp3 expression and regulatory activity in distinct $\mathrm{CD} 4^{+} \mathrm{T}$ cell subsets. J Leukoc Biol 82: 335-346, 2007.

70. Oft M, Heider KH and Beug H: TGFbeta signaling is necessary for carcinoma cell invasiveness and metastasis. Curr Biol 8 . 1243-1252, 1998

71. Zhang HJ, Wang HY, Zhang HT, Su JM, Zhu J, Wang HB, Zhou WY, Zhang H, Zhao MC, Zhang L and Chen XF: Transforming growth factor- $\beta 1$ promotes lung adenocarcinoma invasion and metastasis by epithelial-to-mesenchymal transition. Mol Cell Biochem 355: 309-314, 2011.

72. Lee D, Chung YH, Kim JA, Lee YS, Lee D, Jang MK, Kim KM, Lim YS, Lee HC and Lee YS: Transforming growth factor beta 1 overexpression is closely related to invasiveness of hepatocellular carcinoma. Oncology 82: 11-18, 2012. 
73. Teraoka H, Sawada T, Yamashita Y, Nakata B, Ohira M, Ishikawa T, Nishino $\mathrm{H}$ and Hirakawa K: TGF- $\beta 1$ promotes liver metastasis of pancreatic cancer by modulating the capacity of cellular invasion. Int J Oncol 19: 709-715, 2001.

74. Malaponte G, Zacchia A, Bevelacqua Y, Marconi A, Perrotta R, Mazzarino MC, Cardile V and Stivala F: Co-regulated expression of matrix metalloproteinase- 2 and transforming growth factor- $\beta$ in melanoma development and progression. Oncol Rep 24: 81-87, 2010.

75. Ostroukhova M, Qi Z, Oriss TB, Dixon-McCarthy B, Ray P and Ray A: Treg-mediated immunosuppression involves activation of the Notch-HES1 axis by membrane-bound TGF-beta. J Clin Invest 116: 996-1004, 2006

76. Samon JB, Champhekar A, Minter LM, Telfer JC, Miele L, Fauq A, Das P, Golde TE and Osborne BA: Notch1 and TGFbetal cooperatively regulate Foxp3 expression and the maintenance of peripheral regulatory T cells. Blood 112: 1813-1821, 2008.

77. Zhou J, Jain S, Azad AK, Xu X, Yu HC, Xu Z, Godbout R and $\mathrm{Fu}$ Y: Notch and TGF $\beta$ form a positive regulatory loop and regulate EMT in epithelial ovarian cancer cells. Cell Signal 28 838-849, 2016

78. Zavadil J, Cermak L, Soto-Nieves N and Böttinger EP: Integration of TGF-beta/Smad and Jagged1/Notch signalling in epithelial-to-mesenchymal transition. EMBO J 23: 1155-1165, 2004.

79. Blokzijl A, Dahlqvist C, Reissmann E, Falk A, Moliner A Lendahl U and Ibáñez CF: Cross-talk between the Notch and TGF-beta signaling pathways mediated by interaction of the Notch intracellular domain with Smad3. J Cell Biol 163: 723-728, 2003.

80. Klüppel $\mathrm{M}$ and Wrana JL: Turning it up a Notch: Cross-talk between TGF beta and Notch signaling. BioEssays 27: 115-118, 2005.

81. Barbarulo A, Grazioli P, Campese AF, Bellavia D, Di Mario G, Pelullo M, Ciuffetta A, Colantoni S, Vacca A, Frati L, et al: Notch3 and canonical NF-kappaB signaling pathways cooperatively regulate Foxp3 transcription. J Immunol 186: 6199-6206, 2011.

82. Burghardt S, Claass B, Erhardt A, Karimi K and Tiegs G: Hepatocytes induce Foxp $3^{+}$regulatory T cells by Notch signaling. J Leukoc Biol 96: 571-577, 2014

83. Mota C, Nunes-Silva V, Pires AR, Matoso P, Victorino RM, Sousa AE and Caramalho I: Delta-like 1-mediated Notch signaling enhances the in vitro conversion of human memory CD4 T cells into FOXP3-expressing regulatory T cells. J Immunol 193 5854-5862, 2014

84. Trehanpati N, Shrivastav S, Shivakumar B, Khosla R, Bhardwaj S, Chaturvedi J, Sukriti, Kumar B, Bose S, Mani Tripathi D, et al: Analysis of Notch and TGF- $\beta$ signaling expression in different stages of disease progression during hepatitis B virus infection. Clin Transl Gastroenterol 3: e23, 2012.

85. Luo X, Tan H, Zhou Y, Xiao T, Wang C and Li Y: Notch1 signaling is involved in regulating Foxp3 expression in T-ALL. Cancer Cell Int 13: 34, 2013.

86. Josien H: Recent advances in the development of gamma-secretase inhibitors. Curr Opin Drug Discov Devel 5: 513-525, 2002.

87. Cardile V, Frasca G, Libra M, Caggia S, Umezawa K, Panico A and Malaponte G: Dehydroxymethylepoxyquinomicin inhibits expression and production of inflammatory mediators in interleukin-1beta-induced human chondrocytes. Cell Physiol Biochem 25: 543-550, 2010.

88. Ohnuki H and Tosato G: Notch and TGF $\beta$ : Functional partners facilitating tumor progression. OncoImmunology 3: e29029, 2014.

89. Hoek K, Rimm DL, Williams KR, Zhao H, Ariyan S, Lin A, Kluger HM, Berger AJ, Cheng E, Trombetta ES, et al: Expression profiling reveals novel pathways in the transformation of melanocytes to melanomas. Cancer Res 64: 5270-5282, 2004.

90. Perrot CY, Javelaud D and Mauviel A: Insights into the transforming growth factor- $\beta$ signaling pathway in cutaneous melanoma. Ann Dermatol 25: 135-144, 2013

91. Zhang J, Wang Y, Li D and Jing S: Notch and TGF- $\beta /$ Smad3 pathways are involved in the interaction between cancer cells and cancer-associated fibroblasts in papillary thyroid carcinoma. Tumour Biol 35: 379-385, 2014.

92. Zhang HY and Sun H: Up-regulation of Foxp3 inhibits cell proliferation, migration and invasion in epithelial ovarian cancer. Cancer Lett 287: 91-97, 2010.

93. Wang L, Liu R, Li W, Chen C, Katoh H, Chen GY, McNally B, Lin L, Zhou P, Zuo T, et al: Somatic single hits inactivate the $\mathrm{X}$-linked tumor suppressor FOXP3 in the prostate. Cancer Cell 16: 336-346, 2009
94.Zuo T, Liu R, Zhang H, Chang X, Liu Y, Wang L, Zheng P and Liu Y: FOXP3 is a novel transcriptional repressor for the breast cancer oncogene SKP2. J Clin Invest 117: 3765-3773, 2007.

95.Liu Y, Zhang P, Li J, Kulkarni AB, Perruche S and Chen W: A critical function for TGF-beta signaling in the development of natural $\mathrm{CD} 4{ }^{+} \mathrm{CD} 25^{+} \mathrm{Foxp}^{+}$regulatory T cells. Nat Immunol 9: 632-640, 2008.

96. Brody JR, Costantino CL, Berger AC, Sato T, Lisanti MP, Yeo CJ, Emmons RV and Witkiewicz AK: Expression of indoleamine 2,3-dioxygenase in metastatic malignant melanoma recruits regulatory $\mathrm{T}$ cells to avoid immune detection and affects survival. Cell Cycle 8: 1930-1934, 2009.

97. Chen C, Rowell EA, Thomas RM, Hancock WW and Wells AD: Transcriptional regulation by Foxp3 is associated with direct promoter occupancy and modulation of histone acetylation. J Biol Chem 281: 36828-36834, 2006.

98.Dimitrakopoulos FI, Papadaki H, Antonacopoulou AG, Kottorou A, Gotsis AD, Scopa C, Kalofonos HP and Mouzaki A: Association of FOXP3 expression with non-small cell lung cancer. Anticancer Res 31: 1677-1683, 2011.

99.Franco-Molina MA, Miranda-Hernández DF, MendozaGamboa E, Zapata-Benavides P, Coronado-Cerda EE, SierraRivera CA, Saavedra-Alonso S, Taméz-Guerra RS and Rodríguez-Padilla C: Silencing of Foxp3 delays the growth of murine melanomas and modifies the tumor immunosuppressive environment. OncoTargets Ther 9: 243-253, 2016.

100.Fantini MC, Becker C, Monteleone G, Pallone F, Galle PR and Neurath MF: Cutting edge: TGF-beta induces a regulatory phenotype in $\mathrm{CD} 4^{+} \mathrm{CD} 25^{-} \mathrm{T}$ cells through Foxp3 induction and down-regulation of Smad7. J Immunol 172: 5149-5153, 2004.

101. Selvaraj RK and Geiger TL: A kinetic and dynamic analysis of Foxp3 induced in T cells by TGF-beta. J Immunol 178 7667-7677, 2007.

102. Guo X and Wang XF: Signaling cross-talk between TGF-beta/ BMP and other pathways. Cell Res 19: 71-88, 2009.

103. Wang Y, Shen RW, Han B, Li Z, Xiong L, Zhang FY, Cong BB and Zhang B: Notch signaling mediated by TGF- $\beta /$ Smad pathway in concanavalin A-induced liver fibrosis in rats. World J Gastroenterol 23: 2330-2336, 2017.

104. Yan XC, Cao J, Liang L, Wang L, Gao F, Yang ZY, Duan JL, Chang TF, Deng SM, Liu Y, et al: miR-342-5p is a notch downstream molecule and regulates multiple angiogenic pathways including notch, vascular endothelial growth factor and transforming growth factor $\beta$ signaling. J Am Heart Assoc 5: e003042, 2016.

105. Kared H, Adle-Biassette H, Foïs E, Masson A, Bach JF, Chatenoud L, Schneider E and Zavala F: Jagged2-expressing hematopoietic progenitors promote regulatory $\mathrm{T}$ cell expansion in the periphery through notch signaling. Immunity $25: 823-834$, 2006.

106. Stockhausen MT, Sjölund J and Axelson H: Regulation of the Notch target gene Hes-1 by TGFalpha induced Ras/MAPK signaling in human neuroblastoma cells. Exp Cell Res 310: 218-228, 2005

107. Pisklakova A, Grigson E, Ozerova M, Chen F, Sullivan DM and Nefedova Y: Anti-myeloma effect of pharmacological inhibition of Notch/gamma-secretase with RO4929097 is mediated by modulation of tumor microenvironment. Cancer Biol Ther 17: 477-485, 2016

108. Tas F, Karabulut S, Yasasever CT and Duranyildiz D: Serum transforming growth factor-beta 1 (TGF- $\beta 1$ ) levels have diagnostic, predictive, and possible prognostic roles in patients with melanoma. Tumour Biol 35: 7233-7237, 2014.

109. Takizawa T, Ochiai W, Nakashima K and Taga T: Enhanced gene activation by Notch and BMP signaling cross-talk. Nucleic Acids Res 31: 5723-5731, 2003.

110. Asnaghi L, Ebrahimi KB, Schreck KC, Bar EE, Coonfield ML, Bell WR, Handa J, Merbs SL, Harbour JW and Eberhart CG: Notch signaling promotes growth and invasion in uveal melanoma. Clin Cancer Res 18: 654-665, 2012.

111. Sriuranpong V, Borges MW, Ravi RK, Arnold DR, Nelkin BD, Baylin SB and Ball DW: Notch signaling induces cell cycle arrest in small cell lung cancer cells. Cancer Res 61: 3200-3205, 2001.

112. Thélu J, Rossio P and Favier B: Notch signalling is linked to epidermal cell differentiation level in basal cell carcinoma, psoriasis and wound healing. BMC Dermatol 2: 7, 2002.

113. Panelos J, Tarantini F, Paglierani M, Di Serio C, Maio V,Pellerito S, Pimpinelli N, Santucci M and Massi D: Photoexposition discriminates Notch 1 expression in human cutaneous squamous cell carcinoma. Mod Pathol 21: 316-325, 2008 
114. Banerjee D, Hernandez SL, Garcia A, Kangsamaksin T, Sbiroli E, Andrews J, Forrester LA, Wei N, Kadenhe-Chiweshe A, Shawber CJ, et al: Notch suppresses angiogenesis and progression of hepatic metastases. Cancer Res 75: 1592-1602, 2015.

115. Talora C, Cialfi S, Segatto O, Morrone S, Kim Choi J, Frati L, Paolo Dotto G, Gulino A and Screpanti I: Constitutively active Notch1 induces growth arrest of HPV-positive cervical cancer cells via separate signaling pathways. Exp Cell Res 305: 343-354, 2005.

116. Takebe N, Nguyen D and Yang SX: Targeting notch signaling pathway in cancer: Clinical development advances and challenges. Pharmacol Ther 141: 140-149, 2014.

117. Olsauskas-Kuprys R, Zlobin A and Osipo C: Gamma secretase inhibitors of Notch signaling. Onco Targets Ther 6: 943-955, 2013.

118. Ji X, Wang Z, Geamanu A, Sarkar FH and Gupta SV: Inhibition of cell growth and induction of apoptosis in non-small cell lung cancer cells by delta-tocotrienol is associated with notch-1 down-regulation. J Cell Biochem 112: 2773-2783, 2011

119. Wang M, Wu L, Wang L and Xin X: Down-regulation of Notch1 by gamma-secretase inhibition contributes to cell growth inhibition and apoptosis in ovarian cancer cells A2780. Biochem Biophys Res Commun 393: 144-149, 2010.

120. Hu J, Zhu X and Lu Q: Antiproliferative effects of $\gamma$-secretase inhibitor, a Notch signalling inhibitor, in multiple myeloma cells and its molecular mechanism of action. J Int Med Res 41: 1017-1026, 2013

121. Qi R, An H, Yu Y, Zhang M, Liu S, Xu H, Guo Z, Cheng T and Cao X: Notch1 signaling inhibits growth of human hepatocellular carcinoma through induction of cell cycle arrest and apoptosis. Cancer Res 63: 8323-8329, 2003.

122. Wang L, Qin H, Chen B, Xin X, Li J and Han H: Overexpressed active Notch1 induces cell growth arrest of HeLa cervical carcinoma cells. Int J Gynecol Cancer 17: 1283-1292, 2007.

123. Miranda-Hernández DF, Franco-Molina MA, Mendoza-Gamboa E, Zapata-Benavides P, Sierra-Rivera CA, Coronado-Cerda EE, Rosas-Taraco AG, Taméz-Guerra RS and Rodríguez-Padilla C: Expression of Foxp3, CD25 and IL-2 in the B16F10 cancer cell line and melanoma is correlated with tumor growth in mice. Oncol Lett 6: 1195-1200, 2013
124.Del Papa B, Sportoletti P, Cecchini D, Rosati E, Balucani C, Baldoni S, Fettucciari K, Marconi P, Martelli MF, Falzetti F and Di Ianni M: Notch1 modulates mesenchymal stem cells mediated regulatory T-cell induction. Eur J Immunol 43: 182-187, 2013.

125. Rao P and Kadesch T: The intracellular form of notch blocks transforming growth factor beta-mediated growth arrest in Mv1Lu epithelial cells. Mol Cell Biol 23: 6694-6701, 2003

126. Sun XF, Sun XH, Cheng SF, Wang JJ, Feng YN, Zhao Y, Yin S, Hou ZM, Shen W and Zhang XF: Interaction of the transforming growth factor- $\beta$ and Notch signaling pathways in the regulation of granulosa cell proliferation. Reprod Fertil Dev 28: 1873-1881, 2016.

127. Masuda S, Kumano K, Shimizu K, Imai Y, Kurokawa M, Ogawa S, Miyagishi M, Taira K, Hirai H and Chiba S: Notch1 oncoprotein antagonizes TGF-beta/Smad-mediated cell growth suppression via sequestration of coactivator p300. Cancer Sci 96: 274-282, 2005.

128. Asano N, Watanabe T, Kitani A, Fuss IJ and Strober W: Notch1 signaling and regulatory $\mathrm{T}$ cell function. J Immunol 180 2796-2804, 2008

129. Xu L, Kitani A, Stuelten C, McGrady G, Fuss I and Strober W: Positive and negative transcriptional regulation of the Foxp3 gene is mediated by access and binding of the Smad3 protein to enhancer I. Immunity 33: 313-325, 2010.

130. Tone Y, Furuuchi K, Kojima Y, Tykocinski ML, Greene MI and Tone M: Smad3 and NFAT cooperate to induce Foxp3 expression through its enhancer. Nat Immunol 9: 194-202, 2008.

This work is licensed under a Creative Commons Attribution-NonCommercial-NoDerivatives 4.0 International (CC BY-NC-ND 4.0) License. 